\title{
Zbornik radova 1. hrvatskog kongresa o ruralnom turizmu s međunarodnim sudjelovanjem, "Perspektive razvoja ruralnog turizma", Hvar, 17. - 21. listopada 2007., Hrvatski farmer, Zagreb, 2010., 547 str.
}

Predmetni "Zbornik radova” podijeljen je u pet cjelina: Uvodna izlaganja, Znanstveni radovi, Studije slučaja, Strani radovi i Sažeci autora.

"Uvodna izlaganja" "broje" dva teksta. U prvome, tumače se pojmovi i termini ruralnog turizma, daje se pregled njegovog stanja u Republici Hrvatskoj i pretpostavke razvoja, pokušava se odgovoriti na pitanje jesu li poljoprivreda i turizam osnovne razvojne šanse Hrvatske, predstavljaju se postojeća iskustva i navode se konkretni prijedlozi daljnjeg razvoja ruralnog turizma i njegovih posebnih oblika. U drugom tekstu raspravlja se o tome je li Hrvatskoj potreban seoski turizam i može li on postati realnost, s obzirom da se već 15-ak godina bezuspješno pokušava dokazati da je Hrvatska zemlja za savršeni odmor i u ruralnim sredinama, odnosno na seoskim domaćinstvima. Napori za razvojem ruralnog turizma uspoređuju se sa znanstvenom fantastikom, jer završavaju pisanim materijalima, raspravama, okruglim stolovima i ostalim, bez konkretnog pomaka. No, kako se u članku pokazuje, ruralni turizam je realnost, što se potvrđuje konkretnim podacima o postotku ruralnog područja i bogatstvu sačuvane ruralne kulture, koji potkrjepljuju nužnost odgovaranja sve brojnijim zahtjevima modernih turista za odmorom u turistički nezasićenim i nenapučenim destinacijama.

Trideset tekstova uvršteno je u cjelinu "Znanstveni radovi”. Riječ je člancima koji sa znanstvene strane obrađuju ruralni turizam, njegove pojedine posebne oblike, specifične teme i probleme, a svima je cilj da ih što argumentiranije obrazlože i ponude odgovarajuća rješenja, odnosno smjernice ili, pak, skrenu pozornost na njih i protumače nužnost bavljenja njima. Tako se, primjerice, tumači važnost valorizacije kulturno-povijesne, tradicijske i prirodne baštine u ruralnom turizmu u Hrvatskoj, navode se i analiziraju nove vrste i oblici ruralnog turizma u pojedinim područjima Hrvatske, kao i inovativni turistički proizvodi koji se mogu koristiti kao modeli razvoja ruralnog turizma u Hrvatskoj. Potom, skreće se pozornost na važnost pravilne percepcije okoliša i potrebu njezinog uključivanja u ruralnom turizmu, predstavljaju se i analiziraju pojedini pilot-projekti koji se bave određenim problemskim segmentima u ruralnom turizmu kao što je, na primjer, razvoj 
ljudskih potencijala u ruralnom razvoju. Nadalje, tumači se važnost ugostiteljske djelatnosti, gastronomije i smještaja u agroturizmu, izdvaja se izvorno, autentično i originalno u ruralnom turizmu, što mu daje ulogu nositelja života tradicije u globaliziranim ekonomskim okolnostima, a pozornost je svraćena i na značenje hrane, odnosno mogućnosti stjecanja gastronomskih iskustava u pojedinim ruralnim krajevima u Hrvatskoj kao dodatnoj važnoj vrijednosti koju pruža boravak na agroturizmu. Pojedini znanstveni tekstovi raspravljaju o vrlo važnom turističkom resursu u kontekstu ruralnog turizma - prostoru, čija vrijednost bezrezervno mora biti uzimana u obzir, jer može imati ozbiljne implikacije u socijalnom, ekonomskom, ekološkom i estetskom smislu. Posebno zbog toga jer je ruralni prostor izložen novim izvorima i potrebama, pa ga treba pratiti i podupirati na pravedan i dobro usklađen način. Pozornost je posvećena i marketingu i odnosima s javnošću za koje je argumentirano pokazana važna uloga u kreiranju ponude seoskog turizma, premda oni nisu, do sada, dovoljno razvijeni u ovom segmentu turističke ponude u Hrvatskoj. Primjena, i kontinuitet, marketinga i odnosa s javnošću važni su i zbog imidža koji nastaje kao posljedica njihovog međusobnog djelovanja, što predstavlja najznačajniju komparativnu prednost u odnosu na konkurenciju. Poduzetništvo u ruralnom turizmu obrađeno je kroz više znanstvenih tekstova, koji su pokazali da postoji poduzetnički potencijal na ruralnim područjima u Hrvatskoj, no njega je, prije svega, potrebno ispravno detektirati, kako bi se njegove razvojne mogućnosti realizirale na najbolji način. Nužnim se pokazala potreba provođenja istraživanja profila poduzetnika u ruralnom području, njihovog turističkog potencijala, razvojnih planova i mjera očekivanih od javnog sektora koje bi poticale i pratile poduzetničke razvojne inicijative. Također, pozornost se svratila analizi postojeće legislative koja se odnosi na poduzetništvo, predstavljeni su i primjeri dobre prakse, a predložene su, i protumačene, zanimljive inicijative razvoja poduzetništva na ruralnim područjima kao što je, primjerice, re-ruralizacija, i slično. Znanstvenim tekstovima obuhvaćeni su i neki posebni oblici ruralnog turizma, te posebna turistička ponuda na ruralnim područjima, koji su obrađeni kroz primjere dobre prakse, kao što su kulturni i zdravstveni turizam, gastronomija, pješačke staze/ture, i ostalo.

Sve navedene teme obrađene su prema ujednačenoj metodološkoj strukturi, posjeduju odgovarajući znanstveni aparat i čine skup radova koji mogu poslužiti kao odgovarajući temelj, i poticaj, daljnjim proučavanjima i razradama istih problema, aktivnosti, tema. Oni, nadalje, čine kvalitetni znanstveni prilog, osnovu za znanstveno-istraživačko bavljenje ruralnim turizmom u Hrvatskoj, pokazujući različitosti njegove široke problematike i nužnost njegovog daljnjeg sustavnog znanstvenog promišljanja.

Cjelinu "Stručni radovi" čini 37 tekstova koji "pokrivaju" raznovrsne teme koje se tiču ruralnog turizma. U njima su, primjerice, obrađeni specifični problemi ili osobitosti ruralnog turizma u pojedinim ruralnim područjima Hrvatske, predstavljeni su njegovi novi proizvodi, potom iskustva i problemi u provedbi zakonske regulative (inspekcijski nadzor, i slično), načini dobivanja financijskih sredstava EU za financiranje ruralnog turizma. Nadalje, obrađeni su neki posebni oblici i ponude 
ruralnog turizma (vinske ceste, cikloturizam, eko-etno sela, parkovi prirode, i drugo), načini korištenja novih marketinških alata, posebno onih vezanih za internet i e-poslovanje, a raspravljena je i edukacija koja se tiče ruralnog turizma, njezine specifičnosti i predstavljeni su ogledni primjeri.

Dvije "Studije slučaja" pokazale su mogućnosti revitalizacije tradicijske baštine u ruralnom turizmu kroz primjer područja Krivog puta u senjskom zaleđu i tradicijskog graditeljstva Slavonije i Baranje, potvrdivši njezinu važnost kao jednog od ključnih činitelja razvoja ruralnog turizma.

Cjelina "Zbornika" "Strani radovi” uključuje 10 članaka istraživača/autora iz zemalja u regiji, odnosno predstavnika vodećih europskih institucija koje se profesionalno bave ruralnim turizmom. Riječ je, poglavito, o pregledima i analizama stanja, problema i uspjeha ruralnog turizma u predmetnim zemljama, mogućnostima, prilikama i budućnosti njegovog razvoja, problemima u prenošenju iskustava, načinima korištenja marketinga i potrebama istraživanja u ruralnom turizmu, te, naposljetku, o nekim posebnim oblicima ruralnog turizma (speleoturizam) s primjerima.

"Sažeci" čine posljednju cjelinu, a riječ je o prilozima autora koji do tiskanja "Zbornika" nisu dostavili radove.

"Zbornik radova Prvog hrvatskog kongresa o ruralnom turizmu" nudi 80 -ak vrijednih znanstvenih, stručnih i profesionalnih priloga koji obrađuju pojedine segmente koje zahvaća cjelina ruralnog turizma. Brojnost i raznolikost obrađenih tema raskriva svu složenost predmetnog područja, a pristupi autora načine kako su problemi shvaćeni, nudeći smjernice, prijedloge i rješenja. Također, člancima je skrenuta pozornost na brojne specifičnosti koje uključuje ruralni turizam, o kojima se treba dalje promišljati i sustavnije ih zahvaćati. Do pojave ovoga "Zbornika" nije postojao tako sveobuhvatan skup obrađenih tema koje se tiču ruralnog turizma, te je, stoga, on vrijedan prilog, ne samo znanstveni i stručni, već i temelj koji može poslužiti za proučavanje ruralnog turizma na različitim razinama. Također i onima koji se bave donošenjem strateških odluka koje se tiču ruralnog turizma. Ovaj Zbornik koncepcijski slijedi rad Kongresa, a riječ je o vrijednom izdanju koje znanstvenim i stručnim pristupom, te studijama slučaja obuhvaća sve segmente ruralnog turizma i namijenjen je svima koji su na bilo koji način uključeni, ili se namjeravaju uključiti, u ruralni turistički proizvod. 